\title{
DIAGNOSIS OF HEART DISEASE USING AUTOMATA FINITE STATE ALGORITHM
}

\author{
Tony Yudianto Pribadi ${ }^{*}$; Kartika Handayani²; Angelina Puput giovani ${ }^{3}$; Windu Gata ${ }^{4}$; \\ Masters in Computer Science \\ STMIK Nusa Mandiri \\ www.nusamandiri.ac.id \\ 14002410@nusamandiri.ac.id 1; 14002416@nusamandiri.ac.id 2; 14002338@nusamandiri.ac.id33; \\ windu@nusamandiri.ac.id 4 ; \\ (*) Corresponding Author
}

\begin{abstract}
The heart is a vital organ for humans. If our heart has a problem, it is very dangerous because considering that many deaths are caused by heart disease. With minimal knowledge and information, it is impossible to maintain a healthy heart. Therefore we need an expert who is an expert on the heart and its various diseases. Based on the facts above, this research was created to help diagnose heart health and anticipate heart disease by designing and implementing a web-based pseudocode. In this application, the concept of Finite State Automata (FSA) is applied to realize and capture patterns of heart health diagnoses. In this application, Finite State Automata (FSA) is applied to read a given input symbol from initial state to final state so that the language can be recognized by the machine. Furthermore, the process will be carried out in accordance with the language being read.
\end{abstract}

Keywords: Finite State Automata Algorithm, Heart Disease, Pseudocode.

\begin{abstract}
Abstrak - Jantung merupakan organ vital bagi manusia jika jantung kita mempunyai masalah maka sangat berbahaya sekali mengingat bahwa banyak kematian disebabkan oleh penyakit jantung. Dengan pengetahuan dan informasi yang minim, mustahil untuk dapat menjaga kesehatan jantung. Oleh karena itu dibutuhkan seorang pakar yang ahli tentang jantung dan macam-macam penyakitnya. Berdasarkan fakta diatas, maka Penelitian ini dibuat untuk membantu mendiagnosa kesehatan jantung dan mengantisipasi jika mempunyai resiko penyakit jantung dengan merancang dan mengimplementasikan aplikasi berbasis web yang masih berupa pseudocode. Dalam aplikasi ini, konsep Finite State Automata (FSA) diterapkan untuk mengenali dan menangkap pola diagnosa kesehatan jantung. Dalam aplikasi ini, Finite State Automata (FSA) diterapkan untuk membaca simbol input yang diberikan dari status awal hingga status akhir agar bahasa dapat dikenali oleh mesin.
\end{abstract}

Selanjutnya proses akan dilakukan sesuai dengan bahasa yang dibaca.

Kata Kunci: Algoritma Finite State Automata, Penyakit Jantung, Pseudocode.

\section{INTRODUCTION}

In this modern era, The use of technology or computer science in the world of health is very important, this encourages experts to further develop technology. The computer science component has two main components, first, models and basic ideas about computing, second, engineering techniques for designing computational systems(Saptadi \& Marwi, 2016). Automata is a system consisting of a finite number of states, where each state states information about the previous input, and can also be considered as machine memory. Input to the automata machine is considered a language that the machine must recognize. Then the automata machine makes decisions that indicate whether the input is accepted or not, so that the automata machine can be used to produce a language whose rules are determined by the language(Saputra, Fauziah, \& Gunaryati, 2018). The expert system is a system that uses human knowledge(Nugroho, 2018). The knowledge is put into a computer and then used to solve problems that usually require human expertise or expertise.

Heart disease is the number one killer disease in the world. One of the diseases that we often encounter is coronary heart disease, besides that many cardiovascular diseases are also found, such as heart infections (endocarditis) and hypertension.(Ramadan \& Winata, 2019). Most ordinary people pay very little attention to health, especially heart health. They are reluctant to have their heart health checked because of the lack of service to patients, a lack of medical personnel, especially heart specialists and limited doctor 
working hours. Based on the background of the problems above, a computer application or program is needed that can store the knowledge of an expert to diagnose heart disease and provide consistent, fast and precise results. Based on this opinion, researchers are interested in conducting research related to designing an expert system program(Septiana, 2016) Who is able to make a diagnosis and provide accurate and fast solutions to the symptoms of heart disease. The method used is the Finite state Automata algorithm method (Allauzen \& Riley, 2018) where Finite State Automata is an abstract machine in the form of a mathematical model system with discrete input and output that can recognize the simplest language (regular language) and can be implemented in real terms where the system can be in one of the a finite number of internal configurations are called state (Wicaksono, Amrizal, \& Mumtahana, 2019). In this study, the problem raised was designing a computer application to diagnose heart disease using the Finite State Automata algorithm.

There have been many researches regarding the manufacture of disease diagnosis systems using the Forward Chaining Method to design an application or create a system. In the research entitled "Perancangan Sistem Pakar Diagnosa Penyakit Jantung dengan Metode Forward Chaining"(Nugroho, 2018), " Aplikasi Sistem Pakar Diagnosa Penyakit Pada Anak Bawah Lima Tahun Menggunakan Metode Forward Chaining" (Yanto, Werdiningsih, \& Purwanti, 2017) and the "Sistem Pakar Diagnosa Penyakit THT" (Lisnawita, Van FC, \& Lianda, 2016)

Based on the studies that have been conducted, the researchers will discuss the application of the diagnosis of heart disease using the Finite State Automata algorithm. This system is designed to make it easier for users to check symptoms of heart disease easily and quickly.

This research is expected to provide the following benefits: For the general public to know in advance the early symptoms of heart disease so that they can take appropriate action to deal with the disease without the help of a heart disease specialist. For doctors who specialize in heart disease, this system can be used as an experienced assistant and relieve the workload based on the symptoms felt by the patient.

\section{MATERIALS AND METHODS}

The research that was carried out was completed through stages which were divided into three stages (Yusri, 2015), namely: (1) Needs analysis and data collection in the form of symptoms of heart disease, (2) System design (3) System implementation.

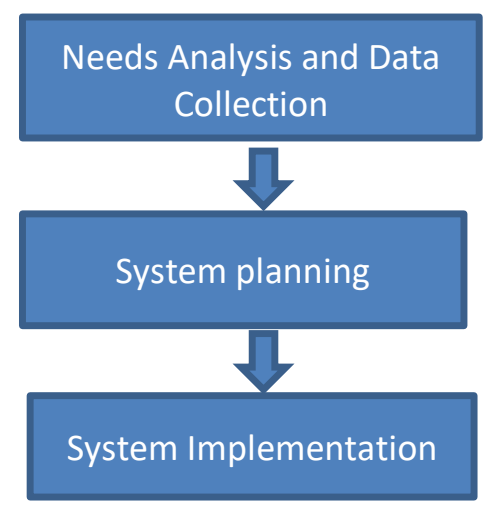

Figure 1 Research Methodology

The research stages, starting with the needs analysis and data collection stage, are collecting and analyzing the symptoms caused by heart disease through literature studies, while the data is collected to build the system. At the stage of making the system design, the use of finite state automata is applied to diagnose heart disease in the form of a flowchart(Nuraini, 2015). The next stage is the implementation and testing of the system, at this stage the system implementation is carried out in the form of a program and system testing and analysis of the implementation of the system that has been made are carried out, whether it is in accordance with the concept of diagnosing heart disease using finite state automata, if there are still errors then it is done improvements so as to get better results.

The system to be built to diagnose heart disease is limited to 7 types and their respective symptoms as shown in Table 1

Table 1 Symptoms of Heart Disease

\begin{tabular}{|c|c|c|c|c|c|c|c|c|}
\hline \multirow[b]{2}{*}{ No. } & \multirow[b]{2}{*}{ Symptoms } & \multicolumn{7}{|c|}{ Heart } \\
\hline & & $\begin{array}{l}\text { Coronar } \\
\text { y heart } \\
\text { disease }\end{array}$ & $\begin{array}{l}\text { Heart muscle } \\
\text { disease } \\
\text { (cardiomyopathy } \\
\text { ) }\end{array}$ & $\begin{array}{l}\text { Ischemic } \\
\text { heart } \\
\text { disease }\end{array}$ & $\begin{array}{l}\text { Heart } \\
\text { failure }\end{array}$ & $\begin{array}{l}\text { Hypertensiv } \\
\text { e heart } \\
\text { disease }\end{array}$ & $\begin{array}{l}\text { Heart } \\
\text { valve } \\
\text { disease }\end{array}$ & $\begin{array}{l}\text { Cardiomegal } \\
\text { y or } \\
\text { hypertrophic } \\
\text { heart }\end{array}$ \\
\hline T01 & Chest pain & $\mathrm{X}$ & & & & & & \\
\hline T02 & $\begin{array}{l}\text { Left Shoulder } \\
\text { feels bad }\end{array}$ & $\mathrm{X}$ & & & & & & \\
\hline T03 & A cold sweat & $\mathrm{X}$ & & & & & & \\
\hline T04 & Out of breath & $\mathrm{X}$ & $\mathrm{X}$ & & $\mathrm{X}$ & & & \\
\hline
\end{tabular}




\begin{tabular}{|c|c|c|c|c|c|c|c|c|}
\hline \multirow[b]{2}{*}{ No. } & \multirow[b]{2}{*}{ Symptoms } & \multicolumn{7}{|c|}{ Heart } \\
\hline & & $\begin{array}{l}\text { Coronar } \\
\text { y heart } \\
\text { disease }\end{array}$ & $\begin{array}{l}\text { Heart muscle } \\
\text { disease } \\
\text { (cardiomyopathy } \\
\text { ) }\end{array}$ & $\begin{array}{l}\text { Ischemic } \\
\text { heart } \\
\text { disease }\end{array}$ & $\begin{array}{l}\text { Heart } \\
\text { failure }\end{array}$ & $\begin{array}{l}\text { Hypertensiv } \\
\text { e heart } \\
\text { disease }\end{array}$ & $\begin{array}{l}\text { Heart } \\
\text { valve } \\
\text { disease }\end{array}$ & $\begin{array}{l}\text { Cardiomegal } \\
\text { y or } \\
\text { hypertrophic } \\
\text { heart } \\
\end{array}$ \\
\hline T05 & Indigestion & $\mathrm{X}$ & & & & & $\mathrm{X}$ & \\
\hline T06 & Nausea & $\mathrm{X}$ & & & & & & \\
\hline T07 & $\begin{array}{l}\text { Irregular } \\
\text { Heartbeat }\end{array}$ & $\mathrm{X}$ & $\mathrm{X}$ & & & & & $\mathrm{X}$ \\
\hline T08 & Dizzy & & $\mathrm{X}$ & & & $\mathrm{X}$ & & \\
\hline T09 & Swollen foot & & $\mathrm{X}$ & & & & $\mathrm{X}$ & \\
\hline T010 & $\begin{array}{l}\text { Heart } \\
\text { palpitations }\end{array}$ & & $\mathrm{X}$ & & & & $\mathrm{X}$ & \\
\hline T011 & Tired Easily & & $\mathrm{X}$ & & & $\mathrm{X}$ & $\mathrm{X}$ & \\
\hline T012 & $\begin{array}{l}\text { Pain in the } \\
\text { middle } \\
\text { area }\end{array}$ & & & $\mathrm{X}$ & & & $\mathrm{X}$ & $\mathrm{X}$ \\
\hline T013 & Sweating easily & & & $\mathrm{X}$ & & & & \\
\hline T014 & Chest Tightening & & & $\mathrm{X}$ & & & & \\
\hline T015 & $\begin{array}{l}\text { Swelling of the } \\
\text { heart }\end{array}$ & & & $\mathrm{X}$ & $\mathrm{X}$ & & & \\
\hline T016 & $\begin{array}{l}\text { Heart } \\
\text { dysfunction }\end{array}$ & & & & $X$ & & & \\
\hline T017 & $\begin{array}{ll}\begin{array}{l}\text { Bleeding } \\
\text { the nose }\end{array} & \\
\end{array}$ & & & & & $\mathrm{X}$ & & \\
\hline T018 & Reddish face & & & & & $\mathrm{X}$ & & \\
\hline T019 & Cough & & & & & & $\mathrm{X}$ & \\
\hline T020 & Stomach ache & & & & & & & $\mathrm{X}$ \\
\hline T021 & Fast heart rate & & & & & & & $\mathrm{X}$ \\
\hline T022 & $\begin{array}{l}\text { Pain in the area } \\
\text { of the left arm }\end{array}$ & $\mathrm{X}$ & & $\mathrm{X}$ & & & & \\
\hline T023 & Back feels bad & $\mathrm{X}$ & & & & & & \\
\hline T024 & Headache & & & & & $\mathrm{X}$ & & \\
\hline
\end{tabular}

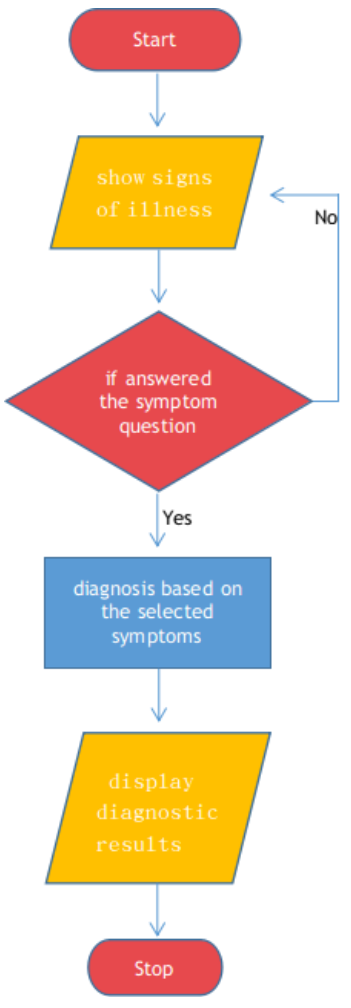

Figure 2 Diagnosis Process of Heart Disease

The design of the Heart Disease Diagnosis Process in Figure 2 is designed to take all the possibilities that can occur during the Heart Disease Diagnosis process. The process in the Figure above will be useful in designing the finite state automata design because all the possibilities are represented. Based on the Design of the Heart Disease Diagnosis Process in the Figure above, a finite state automata design can be made in stages. Every process that occurs is a state / condition in the finite state automata. In designing the diagram for diagnosing heart disease, Non Deterministic Finite Automata (N-DFA) are used.(Gopalakrishnan, 2019). The FSA diagram can be seen in Figure 3.

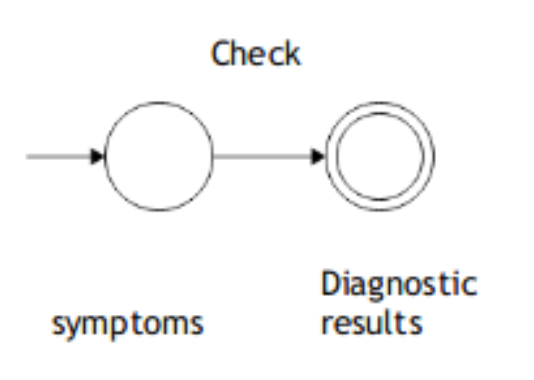

Figure 3 FSA Diagram for Diagnosis of Heart Disease

Figure 3 is a design process diagram of the FSA that was built. The FSA flow diagram steps can be described as follows: a) The start state of the state diagram process is a symptom of heart disease; b) Reading the input checking whether 
experiencing the displayed symptoms or not; and c) Towards the final state in the form of diagnosis results whether or not you have heart disease by accepting checking input. The results of the diagnosis are in accordance with the symptoms experienced.

\section{RESULTS AND DISCUSSION}

This section will discuss in detail the design of the FSA diagram for diagnosing heart disease. This section will also cover the diagnostic process. Based on the symptoms in Table 1 and the design of the FSA diagram, the symptoms will be modeled into a more detailed finite state automata diagram to make a decision. The FSA diagram can be seen in the Figure below.

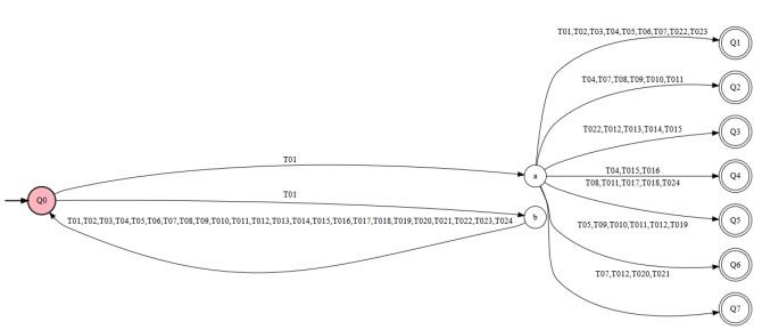

Figure 4 N-DFA State Diagram for Diagnosis of Heart Disease

In the N-DFA diagram for diagnosing heart disease, there are alphabets $\{a, b\}$. These symbols are compared to symptoms experienced and symptoms not experienced, a for having no symptoms and $\mathrm{b}$ for experiencing symptoms. Symbol T01-T024 is an existing state, namely symptoms of heart disease, while Symbols P0, P1, P2, P3, P4, P5, P6 and P7 are states that contain diagnostic results which will be explained as follows:

$\begin{array}{ll}\text { T01 } & \text { : Chest pain } \\ \text { T02 } & \text { : Left Shoulder feels bad } \\ \text { T03 } & \text { : A cold sweat } \\ \text { T04 } & \text { : Out of breath } \\ \text { T05 } & \text { : Indigestion } \\ \text { T06 } & \text { : Nausea } \\ \text { T07 } & \text { : Heartbeat Irregular } \\ \text { T08 } & \text { : Dizzy } \\ \text { T09 } & \text { : Swollen foot } \\ \text { T010 } & \text { : Heart palpitations } \\ \text { T011 } & \text { : Tired Easily } \\ \text { T012 } & \text { : Pain in the middle chest area } \\ \text { T013 } & \text { : Sweat easily } \\ \text { T014 } & \text { : Chest Tightening } \\ \text { T015 } & \text { : Swelling of the heart } \\ \text { T016 } & \text { : Heart function disorders } \\ \text { T017 } & \text { : Bleeding from the nose } \\ \text { T018 } & \text { : Face redness } \\ \text { T019 } & \text { : Cough }\end{array}$

T020 : Stomach ache

T021 : Heartbeat fast

T022 : Pain in the area of the left arm

T023 : Back feels bad

T024 : Headache

P0: Not Heart Disease

P1: Coronary heart disease

P2: Heart muscle disease (cardiomyopathy)

P3: Ischemic heart disease

P4: Heart Failure

P5: Hypertension Heart Disease

P6: Heart Valve Disease

P7: Cardiomegaly or hypertrophic heart

Formally N-DFA in Figure 4 is expressed in 5 tuples or $\mathrm{M}=\left(\mathrm{Q}, \sum, \delta, \mathrm{S}, \mathrm{F}\right)$, meaning:

$\mathrm{Q}=$ set of state $/$ position

$\Sigma=$ the set of input / input / alphabetical symbols

$\Delta=$ transition relation $\mathrm{S}=$ initial state

$\mathrm{F}=$ set of final states

So to state Figure 4 is as follows:

$\mathrm{Q}=$ (T01, T02, T03, T04, T05, T06, T07, T08, T09,

T10, T011, T012, T013, T014, T015, T016, T017,

T018, T019, T020, T021, T022, T023, T024 , P0, P1, P2, P3, P4, P5, P6, P7 $\}$

$\sum=\{\mathrm{a}, \mathrm{b}\}$

$\mathrm{S}=\{\mathrm{T} 01\}$

$\mathrm{F}=\{\mathrm{P} 0, \mathrm{P} 1, \mathrm{P} 2, \mathrm{P} 3, \mathrm{P} 4, \mathrm{P} 5, \mathrm{P} 6, \mathrm{P} 7\}$

$\Delta=$ transition relation can be seen in Table 2 .

Table 2 Relationships

\begin{tabular}{|c|c|c|}
\hline$\Delta$ & $\mathrm{A}$ & $\mathrm{B}$ \\
\hline T01 & P0 & $\mathrm{P} 1$ \\
\hline T02 & P0 & $\mathrm{P} 1$ \\
\hline T03 & $\mathrm{P} 0$ & P1 \\
\hline T04 & P0 & $\mathrm{P} 1, \mathrm{P} 2, \mathrm{P} 4$ \\
\hline T05 & $\mathrm{P} 0$ & P1, P6 \\
\hline T06 & P0 & P1 \\
\hline T07 & P0 & P1, P2, P7 \\
\hline T08 & $\mathrm{P} 0$ & P2, P5 \\
\hline T09 & P0 & P2, P6 \\
\hline T010 & P0 & P2, P6 \\
\hline T011 & P0 & P2, P5, P6 \\
\hline T012 & P0 & P3, P6, P7 \\
\hline T013 & P0 & P3 \\
\hline T014 & P0 & P3 \\
\hline T015 & P0 & P3, P4 \\
\hline T016 & P0 & $\mathrm{P} 4$ \\
\hline T017 & P0 & P5 \\
\hline T018 & P0 & P5 \\
\hline T019 & P0 & P6 \\
\hline T020 & P0 & P7 \\
\hline T021 & P0 & P7 \\
\hline T022 & P0 & P1, P3 \\
\hline T023 & P0 & P1 \\
\hline T024 & $\mathrm{P} 0$ & P5 \\
\hline P01 & - & - \\
\hline P02 & - & - \\
\hline P03 & - & - \\
\hline P04 & - & - \\
\hline P05 & - & - \\
\hline P06 & - & - \\
\hline P07 & - & - \\
\hline
\end{tabular}


Transition relations can also be written by: $\Delta=(((\mathrm{T} 01, \mathrm{a}), \mathrm{p} 0),((\mathrm{T} 01, \mathrm{~b}), \mathrm{p} 1),((\mathrm{T} 02, \mathrm{a}), \mathrm{p} 0)$, ((T02, b), p1), ((T03, a), p0), ((T03, b), p1), ((T04, a), p0), ((T04, b), p1, p2, p4), ((T05, a), p0), ((T05, b), p1, p6), ((T06, a), p0), ((T06, b), p1), ((T07, a), p0), ((T07, b), p1, p2, p7), ((T08, a), p0), ((T08, b), p2, p5), ((T09, a), p0), ((T09, b), p2, p6), ((T10, a), p0), ((T10, b), p2, p6), ((T10, a), p0), ((T10, b), p2, p6), ((T10, a), p0) , ((T10, b), p2, p6), ((T10, a), p0), ((T10, b), p2, p6), ((T10, a), p0), ((T10, b ), p2, p6), ((T10, a), p0), ((T10, b), p2, p6), ((T011, a), p0), ((T011, b), p2, p5, p6), ((T012, a), p0), ((T012, b), p3, p6, p7), ((T013, a), p0), ((T013, b), p3), ((T014, a), p0), ((T014, b), p3), ((T015, a), p0), ((T015, b), p3, p4), ((T016, a), p0), ( (T016, b), p4), ((T017, a), p0), ((T017, b), p5), ((T018, a), p0), ((T018, b), p5), ( (T019, a), p0), ((T019, b), p6), ((T020, a),p0), ((T020, b), p7), ((T021, a), p0), ((T021, b), p7), ((T022, a), p0), ((T022, b), p1, p3), ((T023, a), p0), ((T023, b), p1), ((T024, a), p0), ((T024, b), p5)).

Based on the results of the N-DFA design in Figure 4 , the overall N-DFA design will be discussed as follows.

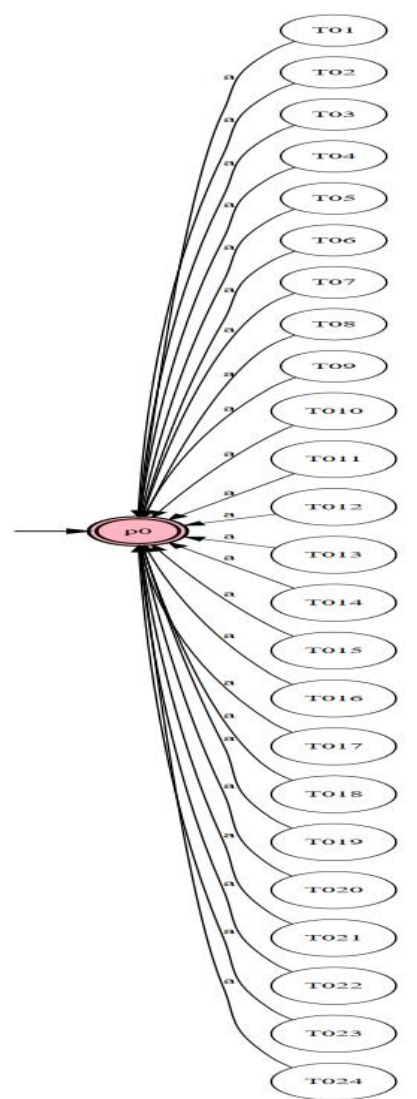

Figure 5 N-DFA State Diagram for Undiagnosed Heart Disease

Figure 5 is the condition of the N-DFA design that is not diagnosed with heart disease. This condition is a condition where at symptom 1 or symptom 2 or symptom 3 or symptom 4 or symptom 5 or symptom 6 or symptom 7 or symptom 8 or symptom 9 or symptom 10 or symptom 11 or symptom 12 or symptom 13 or symptom 14 or symptom 15 or symptoms 16 or symptoms 17 or symptoms 18 or symptoms 19 or symptoms 20 or symptoms 21 or symptoms 22 or symptoms 23 or symptoms 24 not experienced by the user. Transition from state T01 to state T024, if one of the conditions is not fulfilled, it will lead to the final state $\mathrm{p} 0$. The final state $\mathrm{p} 0$ results in an undiagnosed heart disease.

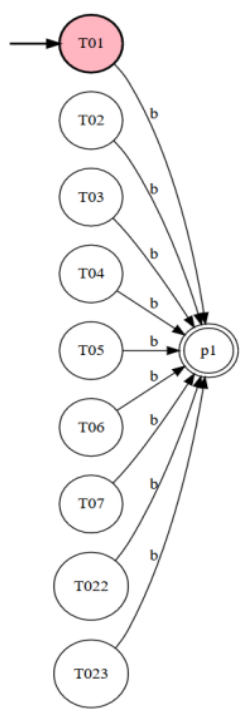

Figure 6 N-DFA State Diagram for diagnosed coronary heart disease

Figure 6 is the condition of the N-DFA design results in which coronary heart disease is diagnosed. This condition is a condition in which symptom 1 , symptom 2 , symptom 3 , symptom 4 , symptom 5 , symptom 6 , symptom 7 , symptom 22 , and symptom 23 must be met all of the conditions. The state flow will then go to the final state $\mathrm{p} 1 \mathrm{which}$ results in a diagnosis of coronary heart disease.

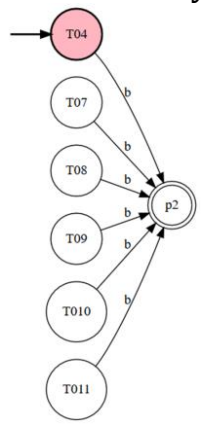

Figure 7 N-DFA State Diagram for a Diagnosed Heart muscle disease

Figure 7 is the condition of the N-DFA design that diagnosed heart muscle disease. This condition is a condition where symptom 4 , symptom 7 , symptom 8 , symptom 9 , symptom 10 , and symptom 011 must all be met. The state flow will then go to the final 
state p2 which results in a diagnosis of heart muscle disease.

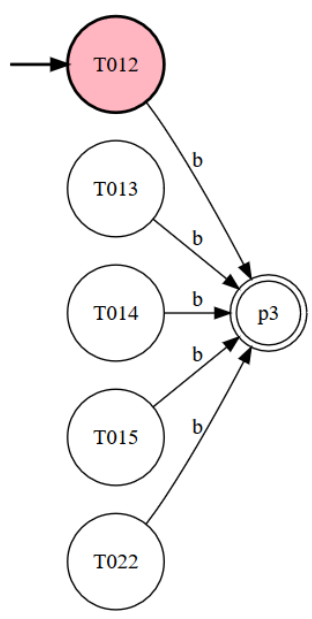

Figure 8 N-DFA State Diagram for a Diagnosed of Ischemic Heart Disease

Figure 8 is the condition of the N-DFA design that is diagnosed with ischemic heart disease. This condition is a condition where symptom 12 , symptom 13 , symptom 14 , symptom 15 , and symptom 022 must all be fulfilled. The state flow will then lead to the final state $\mathrm{p} 3$ which results in a diagnosis of ischemic heart disease..

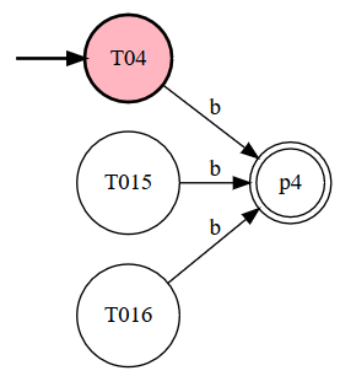

Figure 9 N-DFA State Diagram for a Diagnosed of Heart failure

Figure 9 is the condition of the N-DFA design that diagnosed heart failure. This condition is a condition where in symptom 4 , symptom 15 , and symptom 016 all conditions must be met. The state flow will then go to the final state p4 which results in a diagnosis of heart failure.

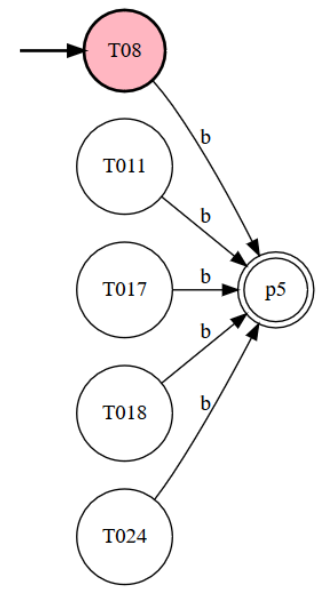

Figure 10 N-DFA State Diagram for a Diagnosed of Hypertensive Heart Disease

Figure 10 is a condition of the results of the $\mathrm{N}$-DFA design in which hypertensive heart disease is diagnosed. This condition is a condition where symptom 8 , symptom 11 , symptom 17 , symptom 18 , and symptom 024 must all be fulfilled. The state flow will then lead to the final state $\mathrm{p} 5$ which results in a diagnosis of hypertension heart disease.

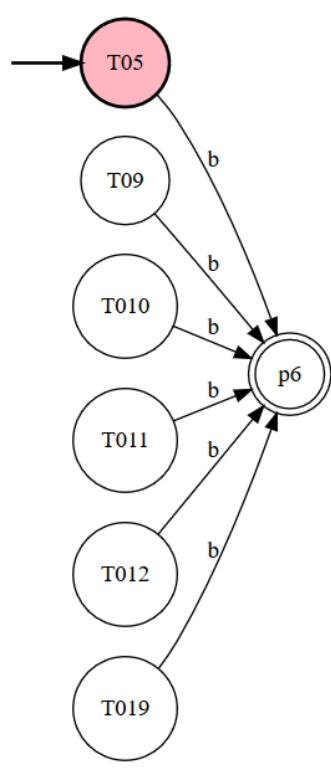

Figure 11 N-DFA State Diagram for a Diagnosed Heart valve disease

Figure 11 is the condition of the N-DFA design in which heart valve disease is diagnosed. This condition is a condition where symptom 5 , symptom 9, symptom 10 , symptom 11 , symptom 12 and symptom 019 must be met all of the conditions. The state flow will then go to the final state $\mathrm{p} 6$ which results in a diagnosis of heart valve disease. 


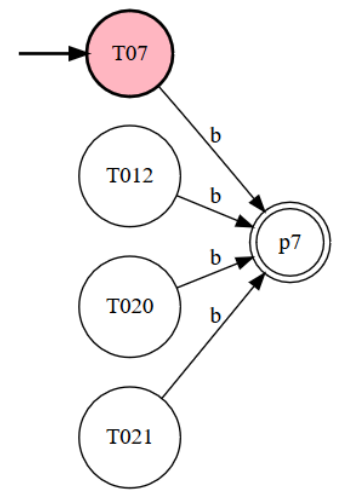

Figure 12 N-DFA State Diagram for a Diagnosed of Hypertrophic Heart Disease

Figure 12 is the condition of the N-DFA design that is diagnosed with hypertrophic heart disease. This condition is a condition where symptom 7 , symptom 12 , symptom 20 , and symptom 021 must be met. The state flow will then lead to the final state $\mathrm{p} 7$ which results in a diagnosis of hypertrophic heart disease..

The algorithm for diagnosing heart disease is based on the previously made Non Deterministic Finite Automata (N-DFA) design (Barua \& Gupta, 2019). The algorithm is in the form of steps to solve problems in the form of diagnosing heart disease. This algorithm will be used to facilitate the preparation of pseudocode before making it into program form. The pseudocode of the process of diagnosing heart disease is as follows:

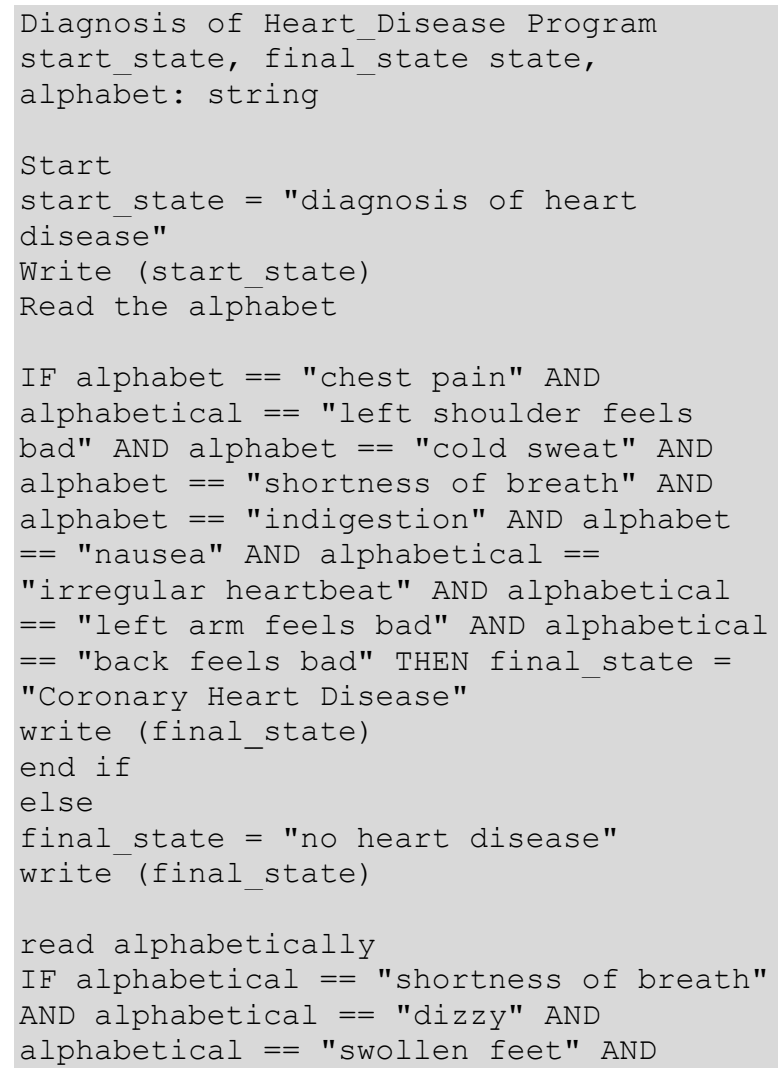

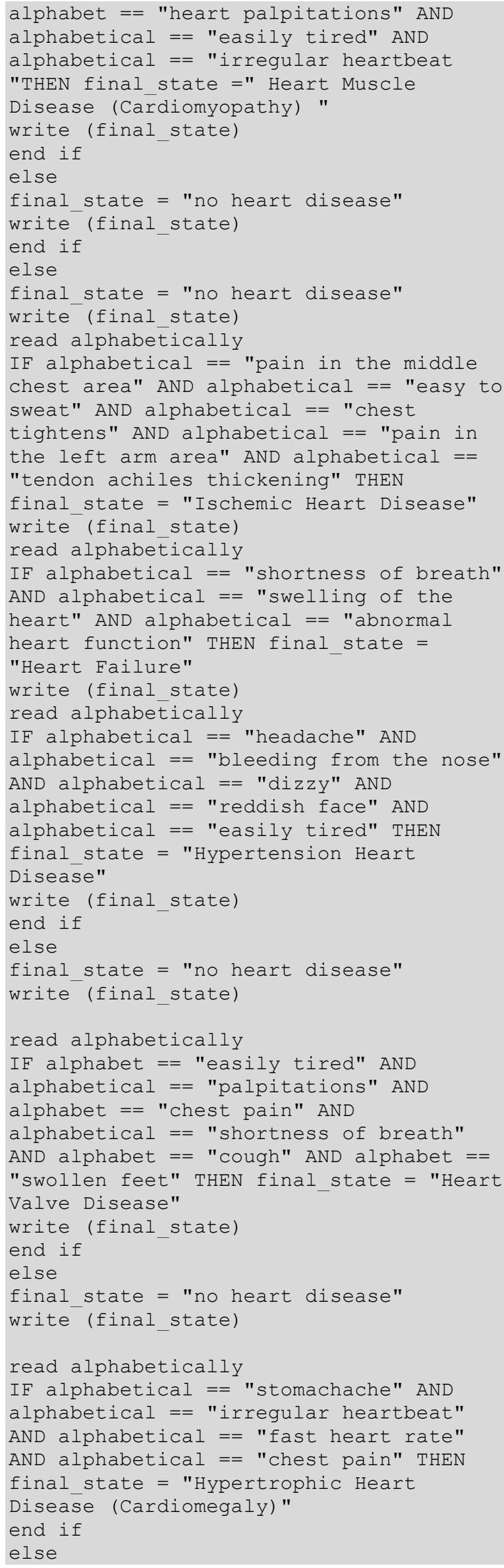




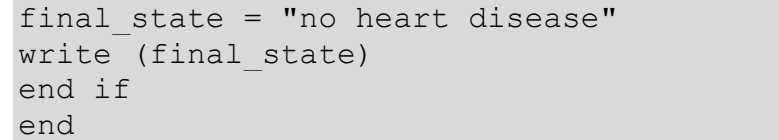

The algorithm for diagnosing heart disease that has been created is applied to making pseudocode into a simple structural programming language. The pseudocode declares the variables to be used and the functions to be used. The existing symptoms are declared as start state and state, while the diagnosis results are in the final state variable. In addition to symptoms and diagnosis, the answers to each symptom question are accommodated in alphabetical variables.

\section{CONCLUSION}

Based on the design, manufacture and implementation of a pseudecode for diagnosing heart disease with the finite state automata algorithm method, diagnosing heart disease with the finite state automata algorithm method is quite helpful in making early diagnoses of heart disease that is felt by ordinary people. In addition, this method is highly dependent on the ability of doctors who are a source of knowledge in making this system. This system is very helpful for everyone because it can be used by many people anywhere and anytime, because it can be web-based and can be a solution for people before consulting directly with a heart specialist.

\section{REFERENCE}

Allauzen, C., \& Riley, M. D. (2018). Algorithms for weighted finite automata with failure transitions. Lecture Notes in Computer Science (Including Subseries Lecture Notes in Artificial Intelligence and Lecture Notes in Bioinformatics), 10977 LNCS, 46-58. https://doi.org/10.1007/978-3-319-948126_5

Barua, R., \& Gupta, K. C. (2019). Finite automata. In Handbook of Mathematical Models for Languages and Computation (pp. 47-86). Institution of Engineering and Technology. https://doi.org/10.1049/PBPC026E_ch5

Gopalakrishnan, G. L. (2019). Nondeterministic Finite Automata. In Automata and Computability (pp. 81-92). Chapman and Hall/CRC. https://doi.org/10.1201/9781315148175-9

Lisnawita, L., Van FC, L. L., \& Lianda, E. (2016). Sistem Pakar Diagnosa Penyakit THT. INOVTEK Polbeng - Seri Informatika, 1(2), 95. https://doi.org/10.35314/isi.v1i2.120

Nugroho, F. A. (2018). Perancangan Sistem Pakar Diagnosa Penyakit Jantung dengan Metode
Forward Chaining. Jurnal Informatika Universitas Pamulang, 3(2), 75. https://doi.org/10.32493/informatika.v3i2.1 431

Nuraini, R. (2015). Desain Algorithma Operasi Perkalian Matriks Menggunakan Metode Flowchart. Jurnal Teknik Komputer Amik Bsi, 1(1), 144-151.

Ramadhan, M., \& Winata, H. (2019). Sistem Pakar Mendiagnosa Gangguna Fungsi Kardiovaskular Dengan Metode Theorema Bayes. Seminar Nasional Sains \& Teknologi Informasi, 513(1), 510-513.

Saptadi, N. T. S., \& Marwi, H. C. (2016). Penyusunan Sistem Evaluasi Kinerja Layanan Dalam Membangun Tata Kelola TI Berbasis Komputasi Awan 1,2. Jatisi, 2(2), 75-86.

Saputra, T. I., Fauziah, F., \& Gunaryati, A. (2018). Simulasi Vending Machine Dengan Mengimplementasikan Finite State Automata. JOINTECS (Journal of Information Technology and Computer Science), 3(3). https://doi.org/10.31328/jointecs.v3i3.819

Septiana, L. (2016). Perancangan Sistem Pakar Diagnosa Penyakit Ispa Dengan Metode Certainty Factor Berbasis Android. Jurnal TECHNO Nusa Mandiri, XIII(2), 89.

Wicaksono, T. H., Amrizal, F. D., \& Mumtahana, H. A. (2019). Pemodelan Vending Machine dengan Metode FSA ( Finite State Automata). DoubleClick: Journal of Computer and Information Technology, 2(2), 66-69. Retrieved from http://ejournal.unipma.ac.id/index.php/doubleclick

Yanto, B. F., Werdiningsih, I., \& Purwanti, E. (2017). Aplikasi Sistem Pakar Diagnosa Penyakit Pada Anak Bawah Lima Tahun Menggunakan Metode Forward Chaining. Journal of Information Systems Engineering and Business Intelligence. https://doi.org/10.20473/jisebi.3.1.61-67

Yusri. (2015). Sistem Informasi Perpustakaan Berbasis Web Pada Smp Frater Makassar. Jurnal Jupiter, 16(2), 66-77. Retrieved from http://ejournal.nusamandiri.ac.id/ejurnal/in dex.php/pilar/article/view/181/157 